\title{
Impact of Interest Rate on the Nifty Auto Sector Index - Evidence from India
}

\author{
Richa Sinha, Seshanwita Das
}

\begin{abstract}
The paper critically examines the interest rate announced by RBI with respect to other factors which it affects and its implications on the Nifty auto sector indices of Indian stock market. The primary objective of the paper is to study the direct impact of interest rate on stock indices and propose a model for forecasting indices based on the interest rate. Karl's Pearson coefficient of correlation and linear regression model is been used to analyse the impact and forecasting. It has been found that there is positive or direct relationship of interest rate on the closing price of the index but not significant.

Index Terms: Interest rate, Nifty Auto indices, Karl Pearson coefficient of correlation, Linear Regression model
\end{abstract}

\section{INTRODUCTION}

For a growing and emerging economy like India, savings and investments are one of the most important components of GDP growth.Savings and investments leads to consumption and production which is directly related to the overall growth of economy. Financial intermediaries and institution both plays an important role in increasing savings and investment. Stock market is among such player which impacts financial and economic growth of the country like India. An efficient stock market provides long term as well as short term investment opportunities and avenues that attract domestics and foreign investments. There are many macro economics factors which affects the stock market and its price - volume movements like interest rate, foreign exchange rates, FII etc. Keeping all other factors aside, this paper tries to explain about the impact of one of the macroeconomic factor i.e. interest rate on the one of the most important and volatile sector i.e Auto sector. This sector is one of the leading sector in India which has many sub parts which impacts directly or indirectly to the economic growth. The buyers and sellers of the sector creates a huge base for consumption as it is fast moving sector these days after Government lays emphasis on the infrastructure development.

\section{LITERATURE REVIEW:}

Volatility in stock market is always been area of interest rate for the researchers for time ago. The movement of price in the stock market creates avenues for short term or long term investment. The most discussed topic and area of researchers were the different factors affecting the volatility of stock market and the study of the extent of impact. It was always been fascinating to track those price movements for the benefits of investors as well as researches as they need a

Revised Manuscript Received on November 22, 2018.

Richa Sinha, Research Scholar, ACCF, Amity University, Noida, Uttar Pradesh, India

Dr Seshanwita Das, Associate Professor, ACCF, Amity University, Noida, Uttar Pradesh, India formula for investments. There were lots of macro economical or behavioural factors which has impacted the volatility. Past researches reveal that one of the macroeconomic factor i.e rate of interest plays a critical role in the volatility of the stock market. Interest rate refers to the bank rate announced by Reserve Bank of India. The MPC in India is responsible for determining the benchmark rate of interest in India. The meeting is been conducted 4 times in a year and their decisions are been announced to the public after their meetings. The benchmark interest rate has its impact on the economic growth of the country. The decision are always been taken in keeping the situation of demand-supply of money in economic.

Few studies which were taken on account are:

Faff, Hodgson and Kremmer (2005) has studied the two deeper impact of interest rate as well as volatility in interest rate through GARCH model (multivariate) ie. dual impact and analysed the other macroeconomic factors and their impact like deregulation. The study was based on the Australian financial stock and it reveals that there is direct/positive impact of changes in regulation and interest rate changes on the stock prices of financial sector. He study was of selected stock.

Uddin and Alam (2009) has concluded negative relationship between the prices and the rate of interest. Their study was focussed on 15 developing and developed countries both. The data studied was of 15 years starting from January 1988 to March 2003. The data establishes inverse relationship between interest rate and stock prices in developed and developing countries. They found that all of the countries interest rate has significant negative relationship with share price and for six countries changes of interest rate has significant negative relationship with changes of share price.

Uddin and Alam (2010) again concluded inverse relationship between rate of interest and stock price. This time the study was focussed on the developing nation i.e Dhaka stock exchange. The study was of 12 year monthly data starting from studied the monthly data from 1992 to 2004. They analysed the stationary test and ordinary least square regression. The results were in sync with their previous finding that interest rate has inverse or negative relationship with growth of share price.

Senthil Kumar (2013) has studied the effect of interest rate changes on stock returns of select Indian commercial banks. He also concluded adverse relationship between interest rate and stock returns of banks. The study was based of the effects of repo rate changes (published by MPC, India) on 13 commercial banks (7 public 

linear regression. So stock returns has negative impact on interest rate.

Muthukumaran and Somasundaram (2014) examined the impact of interest rate and stock returns in Indian stock market and concluded short term effect. The method used were Granger Causality test. They concluded that there is only short term effect of interest rate on stock returns.

P R Kumuda and G Mahesh Komala (2016) researched on the implication of interest rate on the 11 sectors of the Nifty from the period 2005 - 2014. They have used Karl's Pearson's coefficient of correlation and linear regression model to investigate and forecast the stock prices based upon the interest rate. The overall nifty index and 6 out of 11 Nifty sectors has significant impact on the interest rate changes.

\section{OBJECTIVE OF THE STUDY:}

The paper will

1. To examine the impact of interest rate on the Nifty Auto sector index.

2. To create a model for forecasting index movements based on interest rate.

\section{HYPOTHESIS}

H0: There is no impact of interest rate on the Nifty Auto

H1: There is impact of interest rate on the Nifty Auto sector index.

\section{RESEARCH DESIGN}

Data : The objective was to analyse the impact interest rate on Nifty Auto Sector index. The benchmark data of 10 years from April 2009 - Mar 2019 (quarterly) is taken from RBI website and Nifty Auto sector index data of 10 year for the same time period is been taken from the NSE website. The quarterly closing price of the index was considered for research.

Methodology : The closing price of Nifty Auto index is correlated with interest rate to find out any correlation between independent variable i.e. interest rate and dependent variable i.e. closing price of Nifty auto index. The statistical tool used will be Karl's Pearson coefficient of correlation for testing the hypothesis framed and Linear regression for forecasting the index movements.

\section{ANALYSIS AND INTERPRETATION}

The null and alternate hypothesis has been framed and been tested by Karl's Perason coefficient of correlation. Details of the data collection and analysis are been summarised in the table given below: sector banks \& 6 private sector banks). The method used was sector index.

Table 1 : Descriptive summary of the data collected.

\begin{tabular}{|l|c|l|c|}
\hline \multicolumn{2}{|c|}{ RBI benchmark Interest rate } & \multicolumn{2}{c|}{ Nifty Auto Index } \\
\hline Mean & $6.7 \%$ & Mean & 6775.504 \\
\hline Standard Error & $0.1 \%$ & Standard Error & 474.255 \\
\hline Median & $6.5 \%$ & Median & 5228.9 \\
\hline Mode & $6.3 \%$ & Mode & $\# \mathrm{~N} / \mathrm{A}$ \\
\hline Standard Deviation & $0.9 \%$ & Standard Deviation & 3109.898 \\
\hline Range & $3.8 \%$ & Range & 9949.83 \\
\hline Minimum & $4.8 \%$ & Minimum & 1456.32 \\
\hline Maximum & $8.5 \%$ & Maximum & 11406.15 \\
\hline
\end{tabular}

Table 2 : Analysis of Correlation (Acceptance/rejection of null hypothesis)

\begin{tabular}{|l|c|l|}
\hline \multicolumn{1}{|c|}{ Particulars } & Value & \multicolumn{1}{c|}{ Interpretation } \\
\hline Correlation coefficient & 0.22 & Positive impact/relationship \\
\hline $\begin{array}{l}\text { Coefficient of } \\
\text { determination }\end{array}$ & 4.68 & $\begin{array}{l}\text { Not very good fit (4\% of dependent variables are } \\
\text { explained by independent variable) }\end{array}$ \\
\hline P-Value & 0.16 & $\begin{array}{l}\text { Higher than 0.05, null hypotheis rejected. Altemate } \\
\text { Hypothesis accepted. }\end{array}$ \\
\hline
\end{tabular}

The table rejects the null hypothesis. There is impact of interest rate on Nifty Auto index but not much significant. Regression Equation is constructed for forecasting the Auto index. The equation can be explained as below"

$\mathrm{Y}=\mathrm{bx}+\mathrm{a}$

Where $\mathrm{Y}=$ Closing Auto index price

$\mathrm{X}=$ Interest rate

$Y=-73704.2 x+11707.69$

Table 3: Residual output

\begin{tabular}{|c|c|c|}
\hline Observation & Predicted Y & Residuals \\
\hline 1 & 7285.434407 & 1250.915593 \\
\hline 2 & 7101.173907 & 1635.526093 \\
\hline 3 & 6916.913407 & 2075.986593 \\
\hline 4 & 6916.913407 & 1998.186593 \\
\hline 5 & 6916.913407 & 3973.186593 \\
\hline 6 & 7101.173907 & 4054.676093 \\
\hline 7 & 7285.434407 & 4120.715593 \\
\hline 8 & 7285.434407 & 3929.315593 \\
\hline 9 & 7285.434407 & 3735.315593 \\
\hline 10 & 7285.434407 & 3657.265593 \\
\hline
\end{tabular}

\section{LIMITATIONS}

The study focuses on only one sector i.e. Auto sector. Further scope of other sectors is available.

The data (closing price) is been captured on date the interest rate is been announced by RBI.

\section{CONCLUSION}

The data analysis and interpretation shows that there is a positive impact of interest rate on the closing price of Nifty Auto index but not much significant. The auto sector seems not affected much by the monetary policy decisions. The sector is much affected by other macroeconomic factors.

\section{REFERENCES}

1. Md. Gazi Salah Uddin and Md. Mahmudul Alam, International Journal of Business \& Management, Vol: 4 No.3, March 2009, 'Relationship between Interest Rate and Stock Price: Empirical Evidence from Developed and Developing Countries'

2. Haggag, M. M. Analysis of Multiple Linear Regression Models using Symbolic Interval-Valued Variables. 
3. Miyamoto, M. (2016). Predicting Default for Japanese SMEs with Robust Logistic Regression. International Journal of Economics, Commerce and Research (IJECR), 6(3).

4. Robert W. Faff, Allan Hodgson and Michael L. Kremmer, Journal of Business Finance \& Accounting, 32(5) \& (6), June/July 2005, 'An Investigation of the Impact of Interest Rates and Interest Rate Volatility on Australian Financial Sector Stock Return Distributions'.

5. Ali, G., Shah, S. A., \& Anand, V. Opportunities for Private Investment in Transport and Communication Sector of Pakistan.

6. T. Senthil Kumar, Journal of Economics and Management, November 2013; Vol.2 Issue ISSN 2278-0629, ' Effect of interest rate changes on stock returns of select Indian commercial banks'.

7. Thirumagal, P., \& Suresh, S. Payoff and the Impact of Various Investment Attributes on Frequency of Investment in Stock Index Futures.

8. P R Kumuda and G Mahesh Komala, Research Journal of Finance and Accounting, Vol.7, No 21, 2016, ISSN 2222-1697 (paper) ISSN 2222-2847 (online)

9. Webliography

a. www.nse.org

b. www.rbi.org 